\title{
Antioxidants and Vitamins in Clinical Conditions
}

\author{
Z. ZADÁK, R. HYŠPLER, A. TICHÁ, M. HRONEK, P. FIKROVÁ, J. RATHOUSKÁ, \\ D. HRNČIARIKOVÁ, R. ŠTĚTINA
}

Charles University, Faculty of Medicine, Hradec Králové, Czech Republic

Received June 23, 2009

Accepted July 14, 2009

\begin{abstract}
Summary
Various reactive oxygen species (ROS) may be produced from normal biochemical, essential metabolic processes or from external sources as exposure to a variety of agents presented in the environment. Lipids, proteins, carbohydrates and DNA are all capable of reacting with ROS and can be implicated in etiology of various human disorders (rheumatoid arthritis, reperfusion injury, atherosclerosis, lung diseases etc.). In the organism damage by ROS is counteracted with natural antioxidants (glutathione peroxidases, superoxide dismutases, catalase, glutathione, ubiquinol, uric acid, and essential minerals) and nutritional antioxidants from diet (i.e. vitamins E, C, carotenoids). Possible mechanisms of nutritional depletion and side effects of high intake are in the article described.
\end{abstract}

\section{Key words}

Reactive oxygen species $\bullet$ Antioxidants $\bullet$ Vitamins

\section{Corresponding author}

Zdenek Zadak, Charles University, Faculty of Medicine, Šimkova 870, Hradec Králové, Czech Republic. FAX:+420 495834841. E-mail: zadak@fnhk.cz

\section{Introduction}

A radical is any molecule containing one or more unpaired electrons. The participation of oxygen ROS in the pathogenesis of many diseases has been suggested. A variety of markers have been developed to assess oxygen ROS mediated injury. The majority of these markers measure changes in tissue components which are susceptible to oxidation such as lipids, proteins, carbohydrates and DNA (Chaudière 1994). However, most of these markers are not specific for ROS injury, although some specificity could be obtained by measuring changes in the presence of antioxidants. Reactive oxygen species [ROS] may be produced from normal biochemical, essential metabolic processes or from external sources. If the ROS are not inactivated, their high chemical reactivity can damage all types of cellular macromolecules susceptible to oxidation (German 1999).

\section{Oxidative stress}

The term 'oxidative stress' was formerly defined as a disturbance in the pro-oxidant - antioxidant balance leading to potential cellular damage. Another definition of oxidative stress has been proposed as a shift to electron deficient [oxidized] equilibrium. Most cells can tolerate a mild degree of oxidative stress, because they have sufficient antioxidant defense capacity and repair systems, which recognize and remove molecules damaged by oxidation (Babior 1984).

\section{The consequences of oxidative stress}

Cells tolerate mild oxidative stress and respond by activating antioxidant defenses. As mentioned previously, lipids, proteins, carbohydrates and DNA are all capable of reacting with ROS and antioxidants (Halliwel et al. 1991).

\section{Lipids}

Lipids have been extensively studied for their important structural and functional role in cell membranes. Membrane lipids are susceptible to peroxidation after cell death and this phenomenon can lead to misinterpretation of some lipid peroxidation 
Table 1. Cellular components damaged by reactive oxygen species.

$\begin{array}{lll}\text { Lipids } & \text { - } \begin{array}{l}\text { Peroxidation of polyunsaturated fatty acids (PUFA) in organelles } \\ \text { Peroxidation of lipids (cholesterol, PUFA) in cellular membranes } \\ \text { Peroxidation (modification) of low density lipoproteins (LDL) - development of } \\ \text { atherosclerosis }\end{array} \\ \text { - } & \begin{array}{l}\text { Oxidation of SH groups (oxidation of sulfhydryl-containing enzymes), inactivation of enzymes } \\ \text { Oxidative damage of apolipoprotein B (severe modification of LDL) - development of } \\ \text { atherosclerosis }\end{array} \\ \text { Carbohydrates } & \text { - } \begin{array}{l}\text { Polysaccharide depolymerisation } \\ \text { Nucleic acids }\end{array} & \begin{array}{l}\text { Base hydroxylation } \\ \text { Cross - linkage } \\ \text { Scission of DNA strands }\end{array} \\ & \text { Mutations, inhibition of protein, nucleotide and fatty acids synthesis }\end{array}$

assays. Lipid hydroperoxides are detrimental to the structure and function of cell membranes, and are also damaging to membrane proteins such as receptors and enzymes (Katsiki and Manes 2009).

Polyunsaturated fatty acids [PUFA] are particularly susceptible targets for ROS attack. The hydroxyl radical $\left[\mathrm{HO}^{\circ}\right]$ is an important reactive moiety and initiator for ROS chain reaction and lipoperoxidation of PUFA.

\section{Protein}

Protein oxidation can lead to amino acid modification and in particular $\mathrm{HO}^{\circ}$ attacks most amino acid residues in proteins. Thiol [-SH] groups are particularly sensitive to attack by many ROS. Oxidized proteins are more sensitive to proteolysis and an increase in oxidized proteins may be responsible for the loss of selected biochemical and physiological functions. Many proteins bind copper and iron ions and this can make the protein a target of attack by $\mathrm{HO}^{\circ}$. Removal of oxidized proteins is an ongoing process dependent on generation of ROS and antioxidant defense system capacity (Table 1) (Haber and Weiss 1934).

\section{DNA}

DNA fragmentation is frequently seen in cells subjected to oxidative stress. Excessive DNA fragmentation by ROS attack leads to activation of the enzyme poly-(ADP-ribose) polymerase which is activated following peroxide-mediated DNA damage. This enzyme splits the DNA molecule and attaches part of it to proteins in the cell nucleus, possibly to help the DNA repair process. Elimination of seriously damaged cells (Table 1) prevents errors in DNA repair and development of mutations (Chaudière 1994).

One method for determination of damage to DNA is comet assay. This is a versatile and sensitive method for measuring single- and double-strand breaks in DNA (Fig. 1). It can be used for the diagnosis, extent and prevention of DNA damage (epigenetics), methylation, oxidation etc. and determination of the effectiveness of DNA repair (facilitation of DNA repair - antioxidants, drugs, pharmaconutrients) (Collins et al. 2008).

\section{Calcium homeostasis}

Calcium ion is an important mediator of cell injury. Any disturbance that affects the calcium intracellular-extracellular gradient, transport or diffusion has serious consequences for cell function. The calcium ATPase enzymes have critical thiol groups and can be inactivated by ROS.

Damage mediated by ROS can diminish cellular energy production, compromising the ability of cells to maintain $\mathrm{K}, \mathrm{Na}$ and $\mathrm{Ca}$ transport and gradients (Southorn and Powis 1988a,b).

\section{Sources of ROS}

\section{Cellular sources of ROS}

ROS are produced to some extent by all aerobic 
cells through the action of various enzymes and metabolic processes, and also often as a consequence of numerous pathological events including trauma, infections, reperfusion, inflammation, environmental exposure etc (Southorn and Powis 1988b).

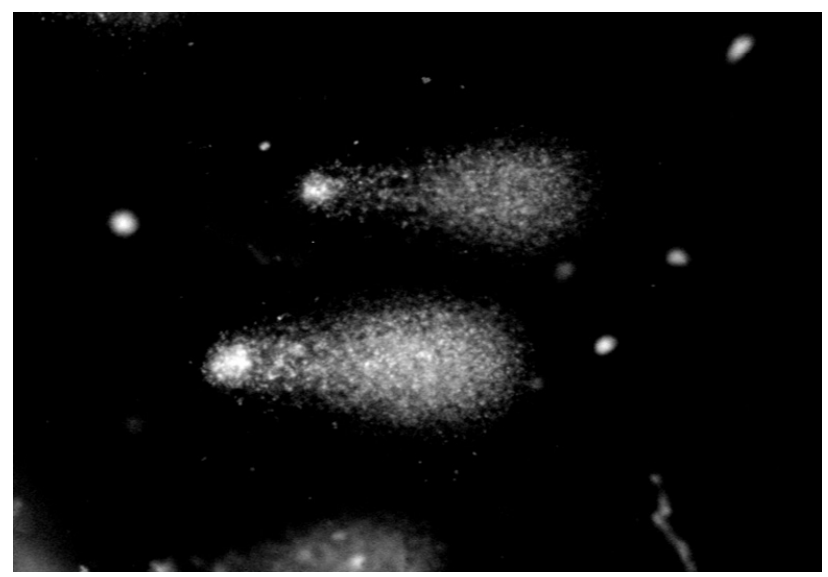

Fig. 1. Comet assay.

\section{Transition metals}

Most metal ions, particularly copper and iron, are essential enzyme cofactors. In the free form these ions in biological systems can facilitate transfer of electrons to susceptible macromolecules such as proteins, lipids and DNA. It is important for organisms that free transition metals in biological fluids are restricted to very low levels. Exposure to redox - active transition metals is controlled primarily through the action of specific chelating proteins such as ceruloplasmin or transferrin (Haber and Weiss 1934).

\section{Mitochondrial electron transport system}

Mitochondria are capable of generating ROS, but in intact mitochondria the rate of production is very low. ROS production is proportional to the rate of mitochondrial oxygen utilization, but is altered in response to various pathological insults (hypoxia, reperfusion, changes in $\mathrm{pH}$, ionic strength, and toxic compounds) (Chaudière 1994).

\section{Phagocytes}

Activated neutrophils and monocytes exhibit a marked increase in oxygen consumption (oxidative burst) involving production of large amounts of ROS. Production of ROS is an important process in the killing of invading organisms or abnormal cells, but on the other hand, the tissue damage produced by ROS liberated from
Table 2. Types of oxidative stress.

\begin{tabular}{|c|c|}
\hline $\begin{array}{l}\text { Nutritional } \\
\text { depletion }\end{array}$ & Possible mechanism \\
\hline$\alpha$-Tocopherol & $\begin{array}{l}\downarrow \text { Scavenging capacity of ROS } \\
\text { and singlet oxygen }\end{array}$ \\
\hline Selenium & Alter membrane structure \\
\hline Zinc or $\mathrm{Cu}$ & $\begin{array}{l}\downarrow \text { GSH peroxidase activity, } \\
\downarrow \text { Zn-Cu superoxide - dismutase }\end{array}$ \\
\hline Ascorbic acid & $\begin{array}{c}\downarrow \text { Scavenging capacity, } \\
\downarrow \text { Vitamin E regeneration, } \\
\text { Disrupt Fe Metabolism }\end{array}$ \\
\hline $\begin{array}{l}\text { Malnutrition and } \\
\text { sulphur AA deplet. }\end{array}$ & $\downarrow$ GSH and antioxidant status \\
\hline Vitamin $A$ & $\begin{array}{c}\text { Alter epithelial metabolism, } \\
\downarrow \text { GSH, SOD, GSH peroxidase }\end{array}$ \\
\hline
\end{tabular}

phagocytic cells can produce injury to surrounding tissues. Continuation of this process can explain the ROS role in the etiology of various human disorders (rheumatoid arthritis, reperfusion injury, atherosclerosis, lung diseases etc.) (Babior 1984).

\section{Environmental exposure}

Oxidative stress may result from exposure to a variety of agents present in the environment. A wide spectrum of chemicals and drugs can cause direct oxidation of biological compounds, resulting in generation of ROS. Internally generated sources of ROS are in mitochondria, peroxizomes, phagocytes, xanthine oxidase, arachidonate pathway, metals, exercise, inflammation, ischemia, and reperfusion. External sources are cigarette smoke, radiation U.V. light, drugs, ethanol, chemical reagents, industrial solvents, and pollution.

\section{Nutritional imbalance}

In the organism there are several mechanisms to counteract damage by ROS and other reactive oxygen species. Important enzymes in this role include glutathione peroxidases, superoxide dismutases and catalase, which decrease concentrations of the most harmful oxidants in the tissues (Kettere and Meyer 1989). Several essential minerals including selenium, copper, manganese and zinc are necessary for the formation or activity of these enzymes. Other elements of the defence system are the antioxidants such as glutathione, ubiquinol and uric acid, 
Table 3. Side effects of high antioxidant intake.

\section{Vitamin C}

Doses over $100 \mathrm{mg} / \mathrm{day} \rightarrow$ urinary excretion of unmetabolized ascorbate

Doses over $500 \mathrm{mg} /$ day $\rightarrow$ no increase of ascorbate concentration in tissue

Risk of vitamin C megadoses:

- increase in oxalate production (35-45\%)

- decreased renal excretion and solubility of uric acid

- $\quad$ renal stone formation ( $\downarrow$ pH, uric acid, oxalates)

- iron overload (enhanced gut absorption)

- destruction of $\mathrm{B}_{12}$ in the gut

- „systemic conditioning“ after megadoses

\section{Vitamin E}

- Tocopherol is one of the least toxic of the vitamins

- Doses $400 \mathrm{mg} /$ day are harmless

- In clinical studies massive doses ( $3000 \mathrm{mg} / \mathrm{day}$ ) have not been found toxic

- Isolated effect of doses over $1000 \mathrm{mg} /$ day

$\rightarrow$ Headache, fatigue, nausea, mild creatinuria, muscular weakness

$\rightarrow$ Prolonged blood clotting time, vitamin K inhibition

$\rightarrow$ Impaired bone mineralisation

\section{Selenium}

Excessive consumption of Se supplements

Selenium-enriched fertilizers

High intake in seleniferous regions (China $\rightarrow 3-5 \mathrm{mg}$ /day)

- Loss of hair, deformity and loss of nails

- Peripheral neuropathy, irritability

- Fatigue, diarrhoea

which are produced during normal metabolism in the body (Becker 1993). Other antioxidants are found in the diet. Although about 4000 antioxidants have been identified, the best known are vitamin $\mathrm{E}$ (Halliwel et al. 2005), vitamin C (Vatassery et al. 1989) and the carotenoids (Burton and Ingold 1984). The antioxidant effect is due to donation of an electron to a rampaging ROS, which destroys it and its capacity to cause damage.

In the normal diet antioxidants and pro-oxidants are present in benign equilibrium. The relative content of antioxidants and pro-oxidants in the diet influences the susceptibility of the organism to oxidative damage. Antioxidant defenses rely closely on vitamins, minerals and natural antioxidants in the diet. Depletion of dietary vitamin $\mathrm{E}$ or overload with polyunsaturated fatty acids is associated with increased formation of lipid peroxidation products and oxidative stress (Witting 1980). Since selenium and ascorbic acid are functionally linked to vitamin $\mathrm{E}$, their nutritional depletion and dietary supplementation have a significant effect on the development of oxidative stress (Table 2). Antioxidant vitamin allowances for humans were established and published in many countries, but variations exist for some vitamins (Menkes et al. 1986).

Some nutritional and clinical conditions require the use of vitamin supplements at high level. In such situations antioxidant vitamins and trace elements are consumed at doses that far exceed requirement level.

The hazards of high (pharmacologic) doses of these nutritional components are presented in Table 3 (Valtueña et al. 2008, Southorn and Powis 1988b).

Antioxidants are clearly important to human life. Supplementation with excessive quantities of antioxidants can shift the oxidant - antioxidant balance toward the antioxidant side (Wolf et al. 2005). The hazard of this nutritional manipulation is not still clear, but the ability of ROS to affect signal transduction, and to modify metabolic processes suggests that antioxidants may be an important factor modulating how an organism will respond to oxidative stress and injury (Southorn and Powis 1988a,b). 


\section{Conflict of Interest}

There is no conflict of interest.

\section{Acknowledgements}

Supported by the Research project MZO 00179906.

\section{References}

BABIOR BM: Oxidants for phagocytes: agents of defense and destruction. Blood 64: 959-966, 1984.

BECKER BF: Towards the physiological function of uric acid. Free Radical Biol Med 14: 615-631, 1993.

BURTON GW, INGOLD KU: $\beta$-carotene: an unusual type of lipid antioxidant. Science 224: 569-573, 1984.

CHAUDIÈRE J.: Some chemical and biochemical constraints of oxidative stress in living cells. In: Free Radical Damage and its Control. RIEE-EVANS CA, BURDON RH (eds), Elsevier, Amsterdam, 1994, pp 25-66.

COLLINS AR, OSCOZ AA, BRUNBORG G, GAIVAO I, GIOVANNELLI L, KRUSZEWSKI M, CATHERINE C, SMITH CC, STETINA R: The comet assay: topical issues. Mutagenesis 23: 143-151, 2008.

GERMAN B: Free radical and antioxidant protocols. Am J Clin Nutr 69: 1295, 1999.

GRODSTEIN F, CHEN J, WALTER C, WILLETT WC: High-dose antioxidant supplements and cognitive function in community-dwelling elderly women. Am J Clin Nutr 77: 975-984, 2003.

HABER F, WEISS J: The catalytic decomposition of hydrogen peroxide by iron salts. Proc R Soc London Ser. A 147: 332-351, 1934.

HALLIWELL B: Reactive oxygen species in living systems - source, biochemistry, and role in human disease. Am $J$ Med 91: S14-S22, 1991.

HALLIWELL B, RAFTER J, JENNER A: Health promotion by flavonoids, tocopherols, tocotrienols, and other phenols: direct or indirect effects? Antioxidant or not? Am J Clin Nutr 81: 268S-276S, 2005.

KATSIKI N, MANES CH: Is there a role for supplemented antioxidants in the prevention of atherosclerosis? Clin Nutr 28: 3-9,2009.

KETTERER B, MEYER DJ: Glutathione transferases: a possible role in the detoxication and repair of DNA and lipid hydroperoxides. Mutat Res 214: 33-40, 1989.

MENKES MS, COMSTOCK GW, VUILLEUMIER JP, HELSING KJ, RIDER AA, BROOKMEYER R: Serum beta carotene, vitamins A and E, selenium and the risk of lung cancer. N Engl J Med 315: 1250-1254, 1986.

SOUTHORN PA, POWIS G: Free radicals in medicine. II. Involvement in human disease. Mayo Clin Proc 63: 390 408, 1988a.

SOUTHORN PA, POWIS G: Free radicals in medicine. I. Chemical nature and biologic reactions. Mayo Clin Proc 63: 381-389, 1988b.

VALTUEÑA S, PELLEGRINI N, FRANZINI L, BIANCHI MA, ARDIGÒ D, DEL RIO D, PIATTI PM, SCAZZINA F, ZAVARONI I, BRIGHENTI F: Food selection based on total antioxidant capacity can modify antioxidant intake, systemic inflammation, and liver function without altering markers of oxidative stress. Am J Clin Nutr 87: 1290-1297, 2008.

VATASSERY GT, SMITH WE, QUACH HT: Ascorbic acid, glutathione and synthetic antioxidants prevent the oxidation of vitamin E in platelets. Lipids 24: 299-304, 1989.

WITTING LA: Vitamin E and lipid antioxidants in free radical initiated reactions. In: Free Radicals in Biology. PRYOR WA (ed), Academic Press, London, 1980, pp 295-319.

WOLF RL, CAULEY JA, PETTINGER M, JACKSON R, ANDREA LACROIX A, LEBOFF MS, LEWIS CE, NEVITT MC, SIMON JA, STONE KL, WACTAWSKI-WENDE J: Lack of a relation between vitamin and mineral antioxidants and bone mineral density: results from the Women's Health Initiative. Am J Clin Nutr 82: $581-588,2005$. 